\title{
THE SENSORY EXAMINATION CAPSULE: SIMULTANEOUS TESTING OF MULTIPLE SENSORY ORGANS
}

\section{Henryk Skarzynski ${ }^{1 A, E-G}$, Anna Krupa ${ }^{2 A-F}$, Justyna Kutyba ${ }^{3 A-F}$, Natalia Czajka ${ }^{2 A, E-G}$, Piotr H. Skarzynski ${ }^{2,4,5 A, E-G}$}

\author{
${ }^{1}$ Oto-Rhino-Laryngology Clinic, World Hearing Center, Institute of Physiology \\ and Pathology of Hearing, Warsaw, Poland \\ ${ }^{2}$ Department of Teleaudiology and Screening, World Hearing Center, \\ Institute of Physiology and Pathology of Hearing, Kajetany, Poland \\ ${ }^{3}$ Tinnitus Department, World Hearing Center, Institute of Physiology \\ and Pathology of Hearing, Warsaw, Poland \\ ${ }^{4}$ Institute of Sensory Organs, Kajetany, Poland \\ ${ }^{5}$ Heart Failure and Cardiac Rehabilitation Department, Faculty of Medicine, \\ Medical University of Warsaw, Warsaw, Poland
}

Corresponding author: Anna Krupa; Department of Teleaudiology and Screening, World Hearing Center, Institute of Physiology and Pathology of Hearing, Mokra 17, 05-830, Kajetany, Poland; email: a.krupa@ifps.org.pl

\begin{abstract} potential to significantly reduce the costs associated with health care by providing earlier and more accurate medical diagnoses.

Key words: telemedicine $\bullet$ screening tests $\bullet$ sense organs

\section{KAPSUŁA BADAŃ ZMYSŁÓW - JEDNOCZESNE BADANIE WIELU NARZĄDÓW ZMYSŁÓW}

Sensory disorders are one of the most common problems in modern society, affecting both communication and quality of life. Most of these disorders can be avoided by performing regular screening tests and minimising risk factors. The objective of this paper is to provide an overview of the modern techniques built into the Sensory Examination Capsule for testing most of the senses. This new screening tool has the

\section{Streszczenie}

Zaburzenia narządów zmysłów są jednym z najczęstszych problemów współczesnego społeczeństwa, wpływających zarówno na komunikację, jak i jakość życia. Większości z tych zaburzeń jesteśmy w stanie uniknąć, wykonując regularne badania przesiewowe i minimalizując czynniki ryzyka. Celem tego artykułu jest przedstawienie przeglądu nowoczesnych technik wbudowanych w Kapsułę Badań Zmysłów w celu przetestowania większości zmysłów. To nowe narzędzie do badań przesiewowych zmysłów może znacznie obniżyć koszty związane z opieką zdrowotną, zapewniając wcześniejsze i dokładniejsze diagnozy medyczne.

Słowa kluczowe: badanie przesiewowe • narządy zmysłów • telemedycyna

\section{Introduction}

Sensory disorders are one of the most common diseases of old age and one of the most common causes of social exclusion and communication disorders in adults [1]. Scientific reports indicate that sensory disorders are also increasing in children $[2,3]$.

According to the World Health Organization (WHO), about $5 \%$ of the entire world population -360 million people, made up of 328 million adults and 32 million children - have been diagnosed with hearing loss. WHO also reports that hearing loss is the biggest problem for people over 65 , affecting about $1 / 3$ of this group. Some predict that by 2025 more than 900 million people worldwide will suffer from hearing loss [4]. WHO believes that half of all hearing loss problems might be avoided by taking preventive measures such as mitigating risk factors and having regular hearing tests [5].

From 2000 to 2011, the Institute of Physiology and Pathology of Hearing (IFPS) in Poland performed hearing screening tests on over half a million school students. The results were that over $20 \%$ of children and adolescents had hearing problems and needed constant or periodic audiological, phoniatric, speech therapy, psychological, or pedagogical care $[6,7]$.

At the same time, WHO estimates that approximately 285 million people have vision problems, while 39 million are blind. The main causes of visual impairment are uncorrected refractive errors - myopia, hyperopia and astigmatism (43\%), unoperated cataracts (33\%), and glaucoma (2\%). Cataracts are an affliction that dominates in low and 
middle-income countries [8]. People with visual impairment are at risk of falling and injuring themselves twice as often as people with good vision. There is also a $4-8$ times higher risk of bone fractures and 3 times higher risk of depression [9]. Eyesight disorders often evoke a sense of limited autonomy, and so patients need institutional assistance 3 years earlier on average than people with no visual impairment. Children with visual impairment are prone to educational problems, which can cause anxiety and cognitive impairment [10]. However, $80 \%$ of all visual disturbances can be avoided or treated, and the earlier the disease is diagnosed, the better the chance of a complete recovery [8]. To increase the chances of successful correction, it is best to have a regular eyesight check with an ophthalmologist - preferably as soon as the first year of life. If no abnormality is detected as a baby, further consultations should be done at ages 2,4 , and 6 years [11].

Vision is also necessary to provide information about body posture and head location, factors that are crucial to balance. Moreover, information about the position and movement of the body comes from the vestibular organ (and both its peripheral and central connections), muscles, and joints. Equilibrium problems require a diagnosis and then therapy. Maintaining balance requires interactions between the vestibular system of the ear, eye, pressure receptors in the foot, and proprioception. The process involves the labyrinth, the vestibular nerve, the vestibular nuclei in the brainstem, and the cerebellum [12]. According to research conducted at IFPS on people over 65, the most common balance disorders are benign paroxysmal positional vertigo (28\%), fear of falling and the consequences of immobilization (22\%), damage to the peripheral vestibular organ (12\%), leukoaraiosis (8\%), cerebellar damage (5\%), and Meniere's disease (4\%) [13]. There is a need for early balance screening to detect disorders and refer the patient for early otoneurological intervention.

An effective sense of smell depends on the correct reception of external stimuli. Within each nostril is an area of epithelium containing millions of receptors which connect to olfactory nerves. The olfactory nerves lead to an area in the brain that is capable of distinguishing an enormous number of odours. Humans have approximately 40 million olfactory cells in an area of 2 by $5 \mathrm{~cm}$ which can distinguish around 1,000 different olfactory sensations. Each smell activates many of them simultaneously although each receptor can respond to many smells. Any process that interferes with the transmission of stimuli from the receptors to the olfactory centres in the brain may cause loss of smell $[14,15]$. The most common causes of loss of smell and taste are diseases of the nose and paranasal sinuses, conditions following upper respiratory tract infection, previous craniocerebral trauma, subarachnoid haemorrhage, multiple inflammation of the cranial nerves, meningitis, diabetes, hypothyroidism, and cirrhosis of the liver. Some commonly used medications can also be the cause of the disorder $[16,17]$.

Proper functioning of the sense organs is essential for living in our modern information society. This is especially true of hearing, which is fundamental for the development of speech and the mastery of spoken language, which we need for interpersonal communication. Partial hearing loss - of various origins, character, and level - leads to

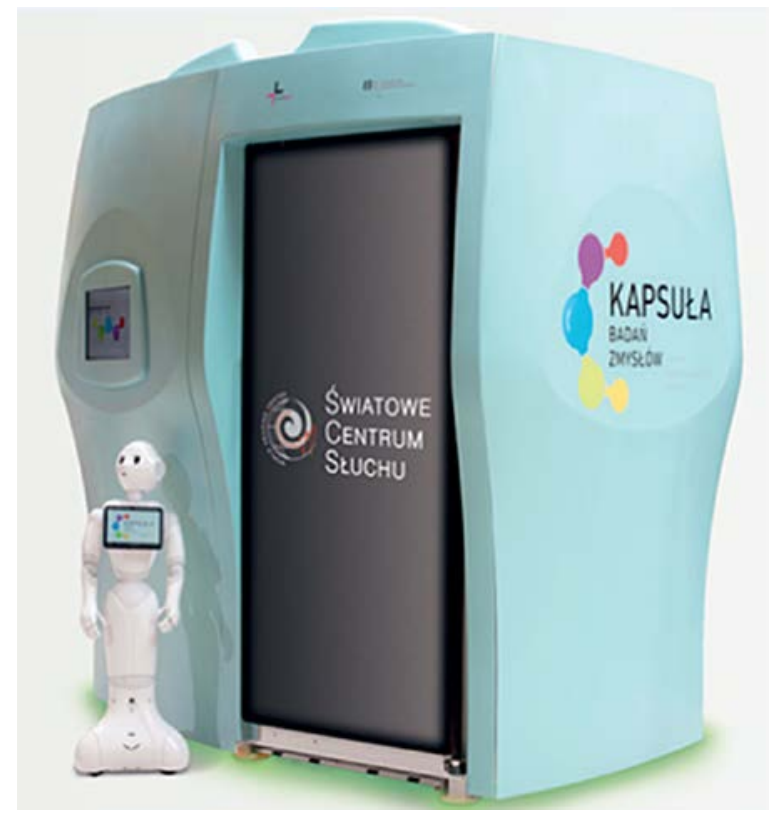

Figure 1. Outside view of the Sensory Examination Capsule

loss of social interaction, and is one of the largest group of disorders affecting a person's daily life $[18,19]$. Modern methods of treatment and rehabilitation are available, but it is important to detect the disorder early through basic screening tests [20-22].

Poor eyesight or sense of balance, and even the sense of smell, are all factors which limit a person's contact with the outside world, hindering communication and thus exposing them to the risk of total exclusion [23-26]. Those affected by various diseases of the sensory organs amount to over 1.5 billion people, affecting babies, infants, and adults alike, but especially the elderly. Unless funding for research on sensory disorders is increased, it is possible that in an ageing European society the problems are likely to get worse [27].

This article aims to familiarize the reader with already available screening tests for each sense and describes the tests incorporated into the Sensory Examination Capsule.

\section{Rationale for the Sensory Examination Capsule}

Screening programs are an important part of public health. Early diagnosis of disorders and initiation of treatment significantly reduces the costs associated with health care. To meet the demand for better and earlier medical diagnoses, the Sensory Examination Capsule was created on the initiative of the director of the Institute of Physiology and Pathology of Hearing, prof. Henryk Skarzyń ski. It is shown in Figure 1.

The project was supported by a consortium consisting of research departments with expertise in the fields of otolaryngology, audiology, and ophthalmology, together with biomedical and materials engineering and telemedicine, and was co-financed by the National Center for Research and Development [28]. The initial aim was to develop a set 


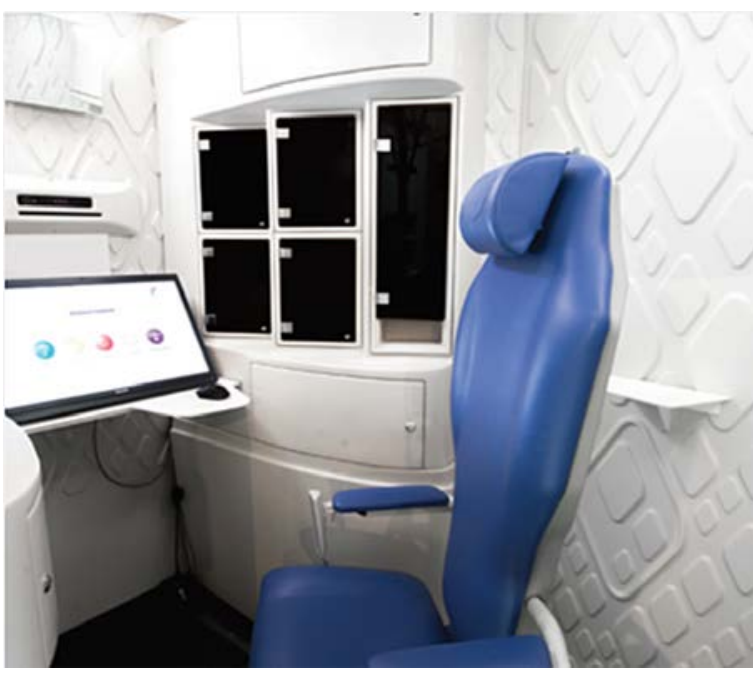

Figure 2. Inside view of the Sensory Examination Capsule ready for seating a patient

of unique medical devices for detecting diseases of the senses - hearing, speech, balance, sight, taste, and smell. An inside view of the device is shown in Figure 2.

All the devices were combined into one multimedia diagnostic and a therapeutic station called the Sensory Examination Capsule. The station can be used to quickly and comprehensively diagnose diseases of the sensory organs and thus provides early detection. Looking more broadly, the device could lower the total cost of diagnosing and rehabilitating diseases of the sensory organs in Poland and throughout Europe, where every fourth person has significant cognitive and communication deficits [29]. Considering the population of seniors, the capsule system could help them with any hearing, sight, or speech disorder. More generally the system makes it possible to economically undertake preventive examinations of any selected population, for example, children.

\section{Complex examinations in one visit}

The Sensory Examination Capsule is a complete system of diagnostic and therapeutic devices all contained in one universal unit, enabling the simultaneous diagnosis of most of the senses (hearing, speech, sight, balance, smell, taste). This makes it possible to perform multiple tests during a single visit without the need to wait for several specialist appointments. The unit allows problems to be quickly identified and referrals made for further treatment. The Capsule is intended to perform large-scale preventive examinations quickly and cheaply, which is ideal for school children or for the elderly. The Capsule's software allows the operator to quickly and easily test each of the senses. In fact, the Capsule makes it possible for a user to conduct a test on themselves using a 'patient portal' - an internet facility that simply requires the user to register and generate a unique login and PIN. When testing is complete, the results are automatically saved to the individual's account. The patient portal can save patient data together with questionnaire results, and has a direct link to the IFPS telemedicine system in Warsaw.

\section{Hearing and central auditory processing disorders}

The Capsule offers tonal audiometry via a Hearing Test Platform which is classed as a class IV audiometer. Central processing tests can also be performed. Tonal audiometry examines a patient's air conduction hearing over the range 250 to $8000 \mathrm{~Hz}$ for losses less than $80 \mathrm{~dB}$. The platform also includes a pitch discrimination test and frequency sequence test to measure the degree of maturity of the auditory system and check right hemisphere brain function. For patients who complain of ringing or buzzing in the ears, the Capsule includes a diagnostic test - the Randomized Test - designed to establish the level of tinnitus.

The Capsule can test a patient's central auditory processing based on the following nine tests.

1) Frequency Pattern Test. During the test, the patient hears two sounds and their task is to say which of them was high and which was low. In the next step, the patient hears three sounds in different sequences (e.g. high-low-high or high-high-low), and the task is to repeat the order in which they were played.

3) Duration Pattern Test. In the first part of the test, the patient hears two sounds and their task is to say which was long and which was short. Then the patient hears three sounds in different sequences (e.g. long-shortlong, short-short-long), and the task is to repeat the sequence in which they were played.

4) Gap Detection Test. The tested person hears a noise in which breaks appear from time to time. The person's task is to verify whether the noise heard was intermittent or uninterrupted sound.

5) Dichotic Digit Test. The patient hears two digits over headphones, one pair given to the right ear and another pair to the left ear. The subject's task is to check off which numbers have been reproduced in both ears.

6) Multi-ear word test. Again over headphones, the patient hears two words given to the right ear at the same time as another two words are given to the left. The task is to repeat which words have been heard.

7) Speech in Noise Test. Noise is reproduced over headphones, and from time to time a word is repeated within the noise. The task is to listen and pick out the word that was played.

8) Compressed Word Test. The test person hears a word that is electronically compressed in time (sometimes called the distorted speech test). The subject's task is to pick out the word.

9) Filtered Word Test. The examined person hears a word whose frequencies are filtered, a so-called frequency distorted speech test. The aim of the test is to pick out which word has been reproduced.

\section{Taste}

In recent months, the importance of taste tests has increased, since with the advent of SARS and COVID-19 one possible symptom is a lack of taste [30,31]. Previously, taste tests were confined mainly to the effect of neurological disease or diabetes mellitus [32-34]. Currently available tests are in the form of taste strips, a pen-like odor dispensing device, taste drops, or thin edible wafers [32-35]. 
In the Sensory Examination Capsule, taste testing is carried out using a self-administered test based on specific gustometry. This is the commonest, quickest, and cheapest way to perform a taste test. There is an envelope containing 5 strips - one is tasteless and the other 4 contain solutions of common flavours: sweet ( $40 \%$ glucose solution); bitter ( $0.6 \%$ quinine); salty ( $25 \%$ sodium chloride); and sour ( $30 \%$ citric acid). The participant takes a paper strip out of its envelope, places it on the centre of the tongue, and closes their mouth for 30 seconds. The person has to identify the taste: sweet, sour, salty, bitter, or no taste.

\section{Smell}

In the last few decades, knowledge of olfactory testing has advanced and we can now easily distinguish normal patients from those with hyposmia (low odour sensitivity) and anosmia (lack of smell) [36,37]. The need for developing taste tests is a difficult issue because the prevalence of olfactory dysfunction is still not well described. There are complex diseases of the nose that can be identified based on other measurable symptoms but the issue still needs additional work (e.g. in cases of adult Refsum's disease) [38]. While attempts have been made to develop accurate tests, research has accelerated significantly during the COVID-19 pandemic and pre-screening and widespread smell testing have been proposed, as they may be predictive of a positive COVID-19 test [39-41].

Smell tests are based on psychophysical olfactometry. The test kit consists of an envelope containing 6 strips painted with different fragrances - cinnamon, banana, ashtray (smoke), leather, chocolate, and gasoline. The patient sniffs a strip and chooses one of 5 possible answers. Both the smell and taste tests are valuable in that they can be used not only to detect the disorder but also to allow long-term monitoring.

\section{Vision}

The literature contains common tests for screening preschool and school children for visual impairment [10,4244]. Others designed for seniors have been extended to test vision acuity for driving or to detect neurological diseases [45]. The most common test for verifying visual impairment is based on visual acuity. Population screening tests are rare, but as recent studies show, they are important for determining whether vision is deteriorating with age [46].

In the Capsule, four tests are used to assess the sense of sight: distance and near vision acuity, contrast sensitivity, and colour. If the patient wears corrective glasses or contact lenses, they are left in place so that the correctness of the lenses can be assessed. All tests assess the patient's vision with a positive or negative test result, and on this basis a referral to an ophthalmologist can be made. The test is a simple and inexpensive method for examining patients of all ages.

\section{Balance}

The balance system is a combination of the sense of sight, an inner sense, and the vestibular organ, and is complex in its operation. So far, no uniform screening test for equilibrium has been developed and using just one test would limit the ability to properly verify imbalance. One approach is to use a questionnaire developed to identify patients at increased risk of falls, which can be used by both primary care physicians and ENT specialists [47].

In previous years, screening tests were based on already known clinical tests, such as the Head Impulse Test, DixHallpike manoeuvre, or Clinical Test of Sensory Integration and Balance (CTSIB). Electronystagmography was also sometimes used to perform the Dix-Hallpike test, vestibular evoked myogenic potentials, caloric test, and rotatory chair [12]. These are common tests which evaluate the two balance reflexes - the vestibular ocular reflex (VOR) and the vestibulospinal reflex (SVR) which regulate body posture. These tests are performed in daily clinical practice whenever a patient reports vertigo or imbalance. However, Polensek et al. (2008) indicated that patients complaining of dizziness who visit a general practitioner (GP) or geriatrician are typically undiagnosed, even for common diseases such as Benign Paroxysmal Positional Vertigo (BPPV) [48].

This points to the need for further guidance to improve healthcare and to develop readily available screening methods to determine if patients need further evaluation. To develop a simple screening test, it was necessary to reduce complexity and the time taken, while still ensuring maximum stimulation of the vestibular organ.

The Sensory Examination Capsule uses a special system for recording and assessing balance. It consists of wireless Frenzel goggles for recording eye movements and software for analysing nystagmus. The test involves two stages of vestibular assessment, the first while standing and a second while sitting. Instructions given to the patient are like those given before a clinical posturography examination using a platform and goggles. The Capsule offers 5 balance tests: 1) spontaneous nystagmus; 2) directional-gaze nystagmus; 3) saccades; 4) free tracking; and 5) optokinetic nystagmus. All tests are performed in the same way as in a clinic. An ENT doctor obtains readings of postural movement and nystagmus (either spontaneous or induced) and the results are presented on a panel. Based on the outcomes, the ENT can decide about referrals for further balance tests. The next step is to make the balance screening program available to a wider population.

\section{Conclusions}

The Sensory Examination Capsule is the only system in the world that allows for simultaneous testing of six sensory organs. In many medical facilities, there is a multitude of diagnostic systems and therapeutic devices for the senses, including peripheral disorders, but so far there has been no way of performing a set of universal sensory diagnostics. The full examination takes $40-45$ minutes for a healthy participant, although the time is longer when the individual has disorders of the sensory organs. The Sensory Examination Capsule presents these unique abilities:

- Shortening the time taken to have a comprehensive diagnosis of multiple sensory organs, thus providing earlier detection of disease.

- Lowering the overall cost of diagnosis and rehabilitation of diseases of the sensory organs in the growing 
number of people affected by these diseases in Poland and in Europe more generally.

- Increasing access to comprehensive diagnosis of diseases that affect every fourth person in Europe and which are associated with significant cognitive and communication deficits.

- Improving the way patients with hearing, sight, and speech disorders interact with the world around them, especially the elderly.

- Provision of economical screening of selected populations, especially children.

So far eight devices have been produced and more than 10,000 tests have been performed. The use of the Sensory Examination Capsule has included, among others, research involving:

1. A national screening as part of the 'Health First' program in 2019

2. International training workshop Window Approach Workshop (WAW)

\section{References}

1. Wie O, Pripp AH, Tvete O. Unilateral deafness in adults: effects on communication and social interaction. Ann Otol Rhinol Laryngol, 2010 Nov 1; 119: 772-81.

2. Hogan A, Shipley M, Strazdins L, Purcell A, Baker E. Communication and behavioural disorders among children with hearing loss increases risk of mental health disorders. ANZ J Public Health, 2011; 35(4): 377-83.

3. Little J-A, Saunders K. A lack of vision: evidence for poor communication of visual problems and support needs in education statements/plans for children with SEN. Public Health, 2015 Feb $18 ; 143-8$.

4. 35 million Americans suffering from hearingloss [viewed 2021-07-2]. Available from https://www.hear-it.org/35-million-Americanssuffering-from-hearing-loss

5. Deafness and hearing loss [viewed 2021-07-1]. Available from https://www.who.int/news-room/fact-sheets/detail/deafness-and -hearing-loss

6. Skarzynski PH, Kochanek K, Skarzynski H, Senderski A, Szkielkowska A, et al. Hearing screening program in school-age children in western Poland. Int Adv Otol, 2011;7(2):194-200.

7. Skarzynski H, Piotrowska A, Szaflik J, Luxon L, Zehnhoff-Dinnesen A, et al. European Consensus Statement on Hearing, Vision, and Speech Screening in Pre-School and School-Age Children. J Hear Sci, 2011 Jun 30; 1(2): 89-90.

8. Vision impairment and blindness [viewed 2021-07-1]. Available from https://www.who.int/news-room/fact-sheets/detail/ blindness-and-visual-impairment

9. Marks R. Falls among the elderly and vision: a narrative review. Open Medicine Journal, 2014 Nov 12; 1(1):54-65.

10. Mathers M, Keyes M, Wright M. A review of the evidence on the effectiveness of children's vision screening. Child Care Health Dev, 2010 Nov; 36(6): 756-80.

11. American Optometric Association. Your Infant's Visual Development. [viewed 2021-07-2]. Available from https://www. brighteyesmeridian.com/eye-care-services/your-eye-health/ childrens-vision/your-infants-visual-development/

12. Waldemar Narozny, Skarżyński H. Zarys Otoneurologii. Vol. 1. Warszawa: Medical Education; 2018. Available from: https://medbook.com.pl/ksiazka/pokaz/id/16150/tytul/zarys-otoneurologiitom-1-2-narozny-skarzynski-medical-education
3. Participation in scientific conferences organized by IFPS.

Our work has been appreciated and awarded with a Gold Medal for Best International Design Award at the Japan Design, Idea \& Invention Expo organized by the World Invention Intellectual Property Associations and Chizai Corporation. In 2021, the Capsule was announced as the Polish Product of the Future during the 23rd session of the Polish Agency for Enterprise Development (PARP) and the National Center for Research and Development (NCBR).

\section{Funding}

The research was undertaken as part of the project 'Mobile Capsule for Senses Examination - a device for screening and diagnosis of senses', co-financed by the Ministry of Science and Higher Education in Poland (decision No. 2/E-523/SPUB/SN/2020).
13.4. Konferencja pt.: „Diagnostyka zaburzeń równowagi” Światowe Centrum Słuchu. [viewed 2021-07-2]. Available from: https://whc.ifps.org.pl/2021/06/4-konferencja-pt-diagnostyka -zaburzen-rownowagi/

14. Walliczek-Dworschak U, Hummel T. The human sense of olfaction. Facial Plast Surg, 2017 Aug; 33(4): 396-404.

15. Marzvanyan A, Alhawaj AF. Physiology, Sensory Receptors. StatPearls Publishing; 2020 [viewed 2021-07-2]. Available from https://www.ncbi.nlm.nih.gov/books/NBK539861/

16. Doty RL. Age-related deficits in taste and smell. Otolaryngol Clin North Am, 2018 Aug; 51(4): 815-25.

17. Doty RL. Treatments for smell and taste disorders: a critical review. Handb Clin Neurol, 2019; 164: 455-79.

18. NIH (US). Study BSC. Information about Hearing, Communication, and Understanding [Internet]. NIH Curriculum Supplement Series. National Institutes of Health; 2007 [viewed 2021-07-2]. Available from: https://www.ncbi.nlm.nih.gov/books/NBK20366/

19. Skarżyński PH, Świerniak W, Gocel M, Tarczyński K, Soćko S, Król B, et al. Program badań przesiewowych słuchu dla uczniów klas pierwszych szkół podstawowych z województwa mazowieckiego. Now Audiofonol, 2020 Oct 20; 9(1): 33-42.

20. Skarzynski H, Lorens A, Piotrowska A, Skarzynski PH. Hearing preservation in partial deafness treatment. Med Sci Monit, 2010 Nov; 16(11): CR555-62.

21. Rostkowska J, Wojewódzka B, Kobosko J, Geremek-Samsonowicz A, Skarżyński H. Możliwości słuchowe dorosłych osób ogłuchłych zaopatrzonych w implant ślimakowy. Now Audiofonol, 2020 Nov 5; 1(1): 46-9.

22. Pankowska A, Rostkowska J, Skarżyński H. Telerehabilitacja dorosłych pacjentów korzystających z aparatów słuchowych i/ lub implantów ślimakowych. Now Audiofonol, 2020 Oct 30; 4(2): 81-5.

23. Bertoni M, Celidoni M, Weber G, Kneip T. Does hearing impairment lead to social exclusion? Ageing in Europe: Supporting Policies for an Inclusive Society. De Gruyter; 2015 [viewed 202107-2]. Available from https://www.degruyter.com/document/ doi/10.1515/9783110444414-010/html 
24. National Academies of Sciences (US). The impact of vision loss. In: Making Eye Health a Population Health Imperative: Vision for Tomorrow. National Academies Press (US); 2016 [viewed 2021-07-2]. Available from https://www.ncbi.nlm.nih.gov/books/ NBK402367/

25. Elkholi SMA, Abdelwahab MK, Abdelhafeez M. Impact of the smell loss on the quality of life and adopted coping strategies in COVID-19 patients. Eur Arch Otorhinolaryngol, 2021 Jan 19; $1-8$.

26. Gobba F. Occupational exposure to chemicals and sensory organs: a neglected research field. NeuroToxicology, 2003 Aug; 24(4-5): 675-91.

27. Ageing Europe: Looking At The Lives Of Older People In The EU. Statistical book. European Union: Publications Office of the European Union, Eurostat; 2019. Available from: https://ec.europa.eu/eurostat/documents/3217494/10166544/KS-02-19\%E2\%80\%91681EN-N.pdf/c701972f-6b4e-b432-57d2-91898ca94893

28. Sensory Examination Capsule showed at the Polish Economic Exhibition entitled "From COP to Economy 4.0", World Hearing Center [viewed 2021-07-2]. Available from https://whc.ifps. org.pl/en/2020/01/sensory-examination-capsule-showed-at-thepolish-economic-exhibition-entitled-from-cop-to-economy-4-0/

29. Promocjabadań przesiewowych w różnych specjalnościach. ŚwiatLekarza. 2018 [viewed 2021-07-2]. Available from https://swiatlekarza. $\mathrm{pl}$ /promocja-badan-przesiewowych-roznych-specjalnosciach/

30. Mullol J, Alobid I, Mariño-Sánchez F, Izquierdo-Domínguez A, Marin C, Klimek L, et al. The loss of smell and taste in the COVID-19 outbreak: a tale of many countries. Curr Allergy Asthma Rep, 2020 Oct; 20(10): 61.

31. Aziz M, Perisetti A, Lee-Smith WM, Gajendran M, Bansal P, Goyal H. Taste changes (dysgeusia) in COVID-19: a systematic review and meta-analysis. Gastroenterol, 2020 Sep; 159(3): 1132-3.

32. Naka A, Riedl M, Luger A, Hummel T, Mueller CA. Clinical significance of smell and taste disorders in patients with diabetes mellitus. Eur Arch Otorhinolaryngol, 2010 Apr 1; 267(4): 547-50.

33. Steinbach S, Hundt W, Vaitl A, Heinrich P, Förster S, Bürger K, et al. Taste in mild cognitive impairment and Alzheimer's disease. J Neurol, 2010 Feb 1; 257(2): 238-46.

34. Cecchini MP, Federico A, Zanini A, Mantovani E, Masala C, Tinazzi M, et al. Olfaction and taste in Parkinson's disease: the association with mild cognitive impairment and the single cognitive domain dysfunction. J Neural Transm (Vienna), 2019 May; 126(5): 585-95.
35. Fjaeldstad A, Niklassen AS, Fernandes HM. Re-test reliability of gustatory testing and introduction of the sensitive Taste-DropTest. Chem Senses, 2018 May 23; 43(5): 341-6.

36. Briner HR, Simmen D. Smell diskettes as screening test of olfaction. Rhinology, 1999 Dec; 37(4): 145-8.

37. Eibenstein A, Fioretti A, Lena C, Rosati N, Ottaviano I, Fusetti M. Olfactory screening test: experience in 102 Italian subjects. Acta Otorhinolaryngol Ital, 2005 Feb; 25(1): 18-22.

38. Gibberd FB. Smell testing: an additional tool for identification of adult Refsum's disease. J Neurol Neurosurg Psychiatry, 2004 Sep 1; 75(9): 1334-6.

39. Karthikeyan P, Sivanand N, Vijayan N, Latheef MN. A clinical study of smell disorders in COVID-19 patients in a tertiary care hospital in Pondicherry: a cross sectional study. Indian J Otolaryngol Head Neck Surg, 2021 Mar 13; 1-6.

40. Hopkins C, Smith B. Widespread smell testing for COVID-19 has limited application. Lancet, 2020 Nov; 396(10263): 1630.

41. Hopkins C, Kelly C. Prevalence and persistence of smell and taste dysfunction in COVID-19; how should dental practices apply diagnostic criteria? BDJ In Pract. 2021 Feb; 34(2): 22-3.

42. Stoll N, Speeg-Schatz C, Sauer A. [Vision screening in children: review of the literature]. J Fr Ophtalmol, 2019 Dec; 42(10): 1116-23.

43. Atowa UC, Wajuihian SO, Hansraj R. A review of paediatric vision screening protocols and guidelines. Int J Ophthalmol, 2019; 12(7): 1194-201.

44. Loh AR, Chiang MF. Pediatric vision screening. Pediatr Rev, 2018 May; 39(5): 225-34.

45. Wettstein M, Wahl H-W, Heyl V. Visual acuity and cognition in older adults with and without hearing loss: evidence for late-life sensory compensation? Ear Hear, 2018 Aug; 39(4): 746-55.

46. Chou R, Dana T, Bougatsos C, Grusing S, Blazina I. Screening for impaired visual acuity in older adults: updated evidence report and systematic review for the US Preventive Services Task Force. JAMA, 2016 Mar 1; 315(9): 915-33.

47. Gos E, Ratajczak A, Tacikowska G, Sosna M, Piłka A, Skarżyński PH Kwestionariusz przesiewowy do oceny zawrotów głowy i zaburzeń równowagi. Now Audiofonol, 2020 Oct 21; 8(2): 37-42.

48. Polensek SH, Sterk CE, Tusa RJ. Screening for vestibular disorders: a study of clinicians' compliance with recommended practices. Med Sci Monit, 2008 May; 14(5): CR238-42. 